\begin{tabular}{|c|c|c|c|}
\hline & $\begin{array}{l}\text { Escola Superior } \\
\text { de Gestäooe } \\
\text { Tecnologia } \\
\text { [ipSantarém] }\end{array}$ & 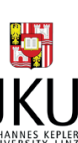 & $\begin{array}{l}\text { ISSN 2029-7564 (online) } \\
\text { SOCIALINĖS TECHNOLOGIJOS } \\
\text { SOCIAL TECHNOLOGIES } \\
2013,3(1) \text {, p. } 85-103\end{array}$ \\
\hline
\end{tabular}

\title{
AGENT-BASED AND MACROSCOPIC MODELING OF THE COMPLEX SOCIO-ECONOMIC SYSTEMS
}

\author{
Aleksejus Kononovičius \\ Vilnius University, Institute of Theoretical Physics and Astronomy, Lithuania, \\ aleksejus.kononovicius@gmail.com \\ Valentas Daniūnas \\ Institute of Lithuanian Scientific Society, Lithuania, mokslasplius@itpa.lt \\ doi:10.13165/ST-13-3-1-06
}

\section{Abstract}

Purpose - The focus of this contribution is the correspondence between collective behavior and inter-individual interactions in the complex socio-economic systems. Currently there is a wide selection of papers proposing various models for the both collective behavior and interindividual interactions in the complex socio-economic systems. Yet the papers directly relating these two concepts are still quite rare. By studying this correspondence we discuss a cutting edge approach to the modeling of complex socio-economic systems.

Design/methodology/approach - The collective behavior is often modeled using stochastic and ordinary calculus, while the inter-individual interactions are modeled using agent-based models. In order to obtain the ideal model, one should start from these frameworks and build a bridge to reach another. This is a formidable task, if we consider the top-down approach, namely starting from the collective behavior and moving towards inter-individual interactions. The bottom-up approach also fails, if complex inter-individual interaction models are considered, yet in this case we can start with simple models and increase the complexity as needed.

Findings - The bottom-up approach, considering simple agent-based herding model as a model for the inter-individual interactions, allows us to derive certain macroscopic models of 
the complex socio-economic systems from the agent-based perspective. This provides interesting insights into the collective behavior patterns observed in the complex socio-economic systems.

Research limitations/implications -The simplicity of the agent-based herding model might be considered to be somewhat limiting. Yet this simplicity implies that the model is highly universal. It reproduces universal features of social behavior and also can be further extended to fit different socio-economic scenarios.

Practical implications - Insights provided in this contribution might be used to modify existing policy making tools in order to cope with the social transformations in the contemporary society.

Originality/Value - The relationship between the inter-individual and the collective behavior is an interesting topic considered to be coming from rather different fields by many scientists. Yet the topic has received due attention only in the recent years. Consequently, the truly systematic approaches directly bridging between these two concepts are somewhat rare. These approaches also differ among themselves - some of the research groups consider questionnaires to understand the individual incentives of the humans, some suggest varying applications of the known physical models and some have roots in the behavioral economics and utility optimization. Our approach in this sense is unique as we start from a simple agentbased herding model and use the ideas from the statistical physics to obtain its macroscopic treatments for the different socio-economic scenarios. In this contribution we present our previous approaches, namely considering new product diffusion in the market and also a financial market model, and also our most recent results, related to the leadership in the social communities and predator-prey type competition in the socio-economic systems. To the best of the authors' knowledge, the correspondence between the considered simple agent-based herding model and the considered macroscopic models was not previously discussed by the other research groups.

Keywords: socio-economic systems, agent-based modeling, stochastic modeling.

Research type: research paper.

\section{Introduction}

The current economic crisis has provoked an active response from the interdisciplinary scientific community. As a result, many papers suggesting what can be improved in understanding of the complex socio-economics systems were published. Some of the most prominent papers on the topic include Bouchaud, 2008; Bouchaud, 2009; Colander et al, 2009; Farmer and Foley, 2009; Farmer et al, 2012; Helbing, 2010; Kitov, 2009; Pietronero, 2008. Most of these papers share the idea that agent-based modeling is essential for the better understanding of the complex socio-economic systems and, consequently, better policy making. Yet in order for an agent-based model to be useful, it should also be analytically tractable, namely it should possess a macroscopic treatment (Cristelli et al, 2012). 
In this contribution we shed a new light on our research group's contributions towards understanding of the correspondence between the inter-individual interactions and the collective behavior. We also provide some new insights into the implications of the global and local interactions, the leadership and the predator-prey interactions in the complex socio-economic systems.

Further, in the Section 2 we provide a scientific background for our work. Section 3 is used to present an agent-based herding model, which was proposed by Kirman (1993) and later analytically treated by Alfarano et al. (2005) and Kononovicius et al (2012). In the Section 4 we compare it with the Bass diffusion model (Kononovicius et al, 2012). Section 5 builds upon the previous material discussed in the Sections 3 and 4 to provide insights into the implications of the global and local interactions in the complex socio-economic systems. In the Section 6 we consider another interesting implication of the base model which provides insights into the phenomenon of leadership in the social communities. The comparison with a widely known and used model, LotkaVolterra model, is given in the Section 7. In the Section 8 we discuss the financial market modeling and relax assumptions previously made in Kononovicius et al, 2012. In the Section 9 conclusions are drawn.

\section{Background}

The contemporary ideas proposed by Bouchaud, 2008; Bouchaud, 2009; Colander et al, 2009; Farmer and Foley, 2009; Farmer et al, 2012; Helbing, 2010; Kitov, 2009; Pietronero, 2008 and others are somewhat reminiscent of the ideas proposed by Axelrod (1998) and Waldrop (1992). In the last decade of the XXth century Waldrop (1992) and Axelrod (1998) have emphasized the importance of understanding the links between the inter-individual and collective behaviors.

In this sense, financial markets prove to be one of the most interesting socioeconomic systems, as there are numerous and rather different examples of both agent-based (Chakraborti et al, 2011; Cristelli et al, 2012; Samanidou et al, 2007) and macroscopic, mainly stochastic, models (Jeanblanc et al, 2009). Cristelli et al (2012) note that so far none of financial market models can be considered to be ideal, as some of the proposed models lack realistic microscopic interaction features, while the others tend to lack analytical tractability.

Excellent example of a realistic, yet not analytically tractable model, is so-called stochastic multi-agent model, which was proposed by Lux and Marchesi (1999). It is considered to be realistic, as it is heavily based on the ideas from the behavioral economics. These ideas are mathematically put down as utility functions, which agents attempt to maximize. Despite this microscopic rationality, the agents are not assumed to be ideally rational - the utility maximization in this model is stochastic. The overly complex mathematical form of the agent-based model, especially due to the use of utility functions, makes the macroscopic treatment of this model appear to be impossible.

Spin model of the financial markets proposed by Bornholdt (2001) is another example of the complex agent-based model. Yet, it is inspired by the model from the 
statistical physics, which is the well-known Ising model used to model phase transitions and magnetic (Sethna, 2009). Spin model serves as an excellent example in the context of this contribution, as it directly draws an important analogy between atoms, agents and individuals. This model perfectly illustrates that, if we consider the statistical behavior of the large number of agents, it might not be that important what do agents represent - inanimate particles or rational individuals. All that actually matters is the essential similarities between the systems, e.g. socio-economic systems are prone to herding behavior, while the spins arranged as a lattice in the Ising model attempt to align themselves in one direction. The spin model of the financial markets is also an interesting example as it, despite its complexity, has recently received a macroscopic treatment. The approach by Krause et al (2012) was possible only due to spin model's relationship with the Ising model, consequently, allowing direct usage of the well-developed mean-field methods from the statistical physics.

Minority Game, inspired by the "El Farol bar problem" (Arthur, 1994), is another agent-based model possessing macroscopic treatment (Challet et al, 2000). In this game the agents attempt to select the least popular of the available states. In the original formulation of the model agents opt to stay home or to visit a bar. If the majority of agents visits the bar, it is over-crowded and agents have a bad time. On the other hand, if the minority of agents visits the bar, they are able to have a good time. In the financial markets the two options are assumed to be opting to buy or to sell. If the majority of agents opts to sell, the prices and, consequently, the profits drop. On the other hand, if the minority of agents sells their stock, they are able to reap large profits as the prices soar. The formulation of the model is relatively simplistic and thus has a macroscopic treatment (Challet et al, 2000).

The latest attempt to propose simple, realistic and analytically tractable model was done by Feng et al. (2012). This attempt is unique, as it uses trader survey data and the empirical observations of the individual interactions to construct an agent-based model. The obtained agent-based model is simple enough to be treated macroscopically. The drawback of this approach is that it operates only on the daily and weekly scales.

Our group contributes to this trend by working on the agent-based herding model proposed by Kirman (1993). As our group has already proposed a macroscopic model for the trading activity (Gontis, 2008) and the absolute return (Gontis, 2010) in the financial markets, we aim to understand the relationship between these models and the agentbased herding model. Interestingly enough, the agent-based herding model relates not only to the models previously proposed by us, but also to the some other well-known macroscopic models (Kononovicius et al, 2012). A similar mindset can be found in a series of papers by Alfi et al $(2009 \mathrm{a} ; 2009 \mathrm{~b})$. Alfi et al (2009a; 2009b) proposed a set of minimal agent-based models needed to recover the essential statistical features of the financial markets, mainly power-law distribution and certain dynamical self-organization features. 


\section{The agent-based herding model and its macroscopic treatment}

In his seminal paper Kirman (1993) noticed that very similar behavioral patterns are observed in rather distinct systems. This discovery led him to an agent-based model capturing very general features of the social behavior.

Kirman credits Pasteels et al (1987) as the first ones to observe a very interesting phenomenon - social insects acting asymmetrically in apparently symmetric setup. This group of entomologists observed the ant colony connected to the two identical food sources. Logically, one would expect that the both food sources would be used equally, yet at any given time the majority of ants used only one of the available food sources. From time to time the preferred food source was switched. Interestingly enough, these switches were triggered not by the exogenous forces, but by the system itself.

In a statistical sense, human crowds tend to behave quite similarly. Kirman (1993) cites numerous papers which note that the people tend to choose the more popular product over the less popular one, even if both products are of the similar quality. Apparently, the same ideas can even be applied to understand the dynamics of the financial markets.

Taking these observations into account, Kirman (1993) proposed a simple one-step transition model (see Figure 1 for the schematic representation of the model). In this model the probabilities for each single agent to switch the currently used food source are given by:

$$
\mu_{1}(X, N)=\sigma_{2}+h(N-X), \quad \mu_{2}(X, N)=\sigma_{1}+h X
$$

The above transition probabilities are defined per agent and per unit of time. Yet, they can be used to obtain system-wide transition probabilities for very short time periods, $\Delta t$. In such case only one transition per single time period is probable (Alfarano et al, 2005):

$$
\begin{aligned}
& P(X \rightarrow X-1)=X \mu_{1}(X, N) \Delta t=X\left[\sigma_{2}+h(N-X)\right] \Delta t \\
& P(X \rightarrow X+1)=(N-X) \mu_{2}(X, N) \Delta t=(N-X)\left(\sigma_{1}+h X\right) \Delta t
\end{aligned}
$$

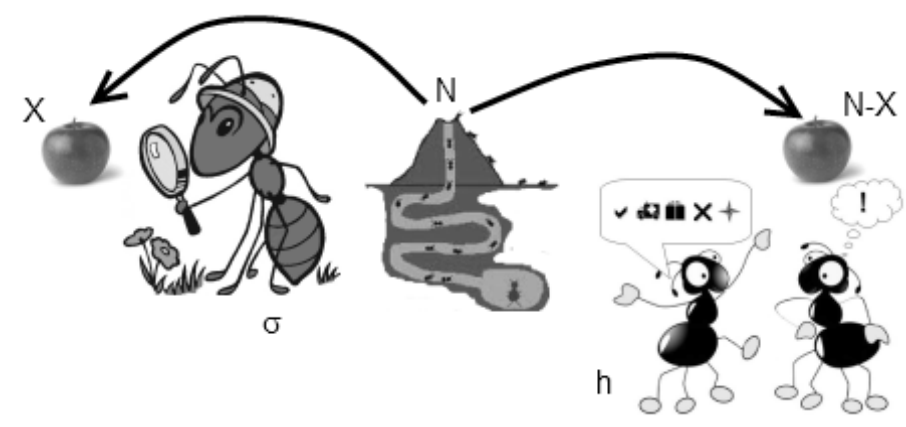


Figure 1. Schematic representation of the Kirman's model. Note that the ant colony is composed of a fixed number of ants, $N$. The ants use the left food source, $X$ ants, or the right food source, $N-X$ ants. Each ant chooses the used food source based on their individual preference, $\sigma$ terms, or due to the influence of the other ants, $h$ terms. In this scheme the food sources are assumed to be identical, yet in a more general setup two distinct individual preference terms, $\sigma_{1}$ and $\sigma_{2}$, should be included.

In order to obtain a macroscopic treatment for this agent-based herding model, let us assume that the number of agents is large enough, nearly infinite, to secure the continuity of the system state defined as $x=X / N$. For $x$ we can define a continuous one-step transition probabilities per unit of time, $\pi^{ \pm}$, which relate to the discrete onestep transition probabilities,

$$
P(X \rightarrow X \pm 1)=N^{2} \pi^{ \pm}(X / N) \Delta t .
$$

The master equation for such process, by using birth-death process formalism (van Kampen, 2007) and by taking $\omega(x, t)$ as a probability to find the system in state $x$ at time $t$, is given by

$$
\partial_{t} \omega(x, t)=N^{2}\left\{\left(\mathbf{E}^{+}-1\right)\left(\pi^{-}(x) \omega(x, t)\right)+\left(\mathbf{E}^{-}-1\right)\left(\pi^{+}(x) \omega(x, t)\right)\right\}
$$

where $\mathbf{E}^{ \pm}$are the one-step, increment and decrement, operators,

$$
\mathbf{E}^{ \pm}[f(x)]=f(x \pm \Delta x) \approx f(x) \pm \Delta x \partial_{x} f(x)+\frac{\Delta \mathrm{x}^{2}}{2} \partial_{x}^{2} f(x), \Delta x=\frac{1}{N} .
$$

The above equation also provides an approximate expression for the one-step operator acting on any continuous function, $f(x)$. By putting these approximations into the master equation, the Fokker-Planck equation is obtained,

$$
\partial_{t} \omega(x, t)=-\partial_{x}\left[N\left\{\pi^{+}(x)-\pi^{-}(x)\right\} \omega(x, t)\right]+\frac{1}{2} \partial_{x}^{2}\left[\left\{\pi^{+}(x)+\pi^{-}(x)\right\} \omega(x, t)\right] .
$$

The stochastic differential equation (abbr. SDE) corresponding to the above FokkerPlanck equation is given by (Gardiner, 2009)

$$
\mathrm{d} x=N\left[\pi^{+}(x)-\pi^{-}(x)\right] \mathrm{d} t+\sqrt{\pi^{+}(x)+\pi^{-}(x)} \mathrm{d} W .
$$

In the agent-based herding model case we obtain (Alfarano et al, 2005; Kononovicius et al, 2012)

$$
\mathrm{d} x=\left[\sigma_{1}(1-x)-\sigma_{2} x\right] \mathrm{d} t+\sqrt{2 h x(1-x)} \mathrm{d} W .
$$


As you can see in Figure 2, time series obtained from the agent-based and stochastic models have the same probability density functions. This serves as an additional proof that the agent-based and stochastic models are equivalent.

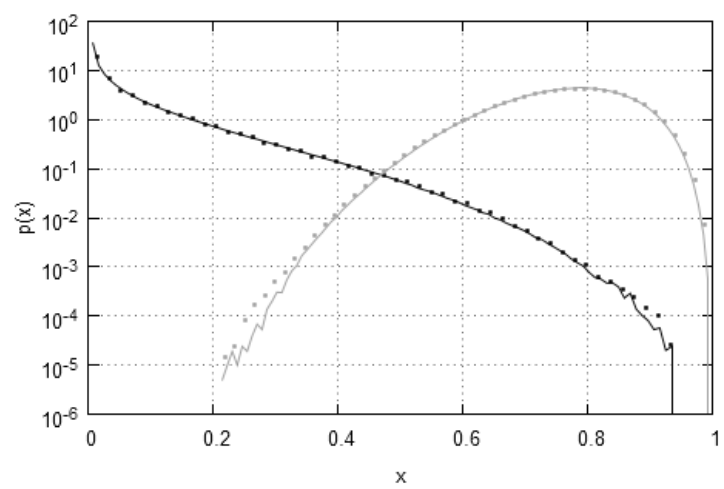

Figure 2. The probability density functions obtained from the macroscopic, stochastic (curves) and the agent-based herding models (dots) in two distinct cases. Black curves and dots were obtained using $\sigma_{1}=0.2, \sigma_{2}=5$ parameter set, while gray curves and dots were obtained using $\sigma_{1}=16, \sigma_{2}=5$ parameter set. Other model parameters: $h=1$ and $N=1000$ (in all applicable cases).

The interactive programs of the agent-based and stochastic models are available online (see (Kononovicius, 2010) and (Kononovicius and Gontis, 2010)).

\section{Bass diffusion model as a special case of the agent-based herding model}

The Bass diffusion model is a prominent model in the marketing science, which is used to forecast the adoption rates of the new durable product (Prasad and Mahajan, 2003). This model assumes, from the empirical point of view, that the potential consumers tend to adopt new product due to the advertising campaigns and interactions with other individuals, imitation. These assumptions were mathematically formalized as an ordinary differential equation:

$$
\partial_{t} X(t)=[N-X(t)]\left[\sigma+\frac{h}{N} X(t)\right], \quad X(0)=0,
$$

where $X(t)$ is a total number of consumers at a given time $t, N$ is a market potential, $\sigma$ is the efficiency of advertising and $h$ is the imitation coefficient.

The agent-based herding model might be used as an agent-based alternative to the Bass diffusion model. Yet, the agent-based herding model needs to account for the 
durability of the product, which makes the transition from the consumer to the potential consumer impossible, (Kononovicius et al, 2012)

$$
P(X \rightarrow X-1)=0, \quad P(X \rightarrow X+1)=(N-X)\left(\sigma_{1}+\frac{h}{N} X\right) \Delta t .
$$

The macroscopic model for this unidirectional agent-based herding model is identical to the mathematical form of the Bass diffusion model (Kononovicius et al, 2012). As we can see in Figure 3, the agreement between the Bass diffusion model and the unidirectional agent-based herding model is good and improves with the increasing size of the system.

The interactive program of this model is available online (Kononovicius et al, 2011).
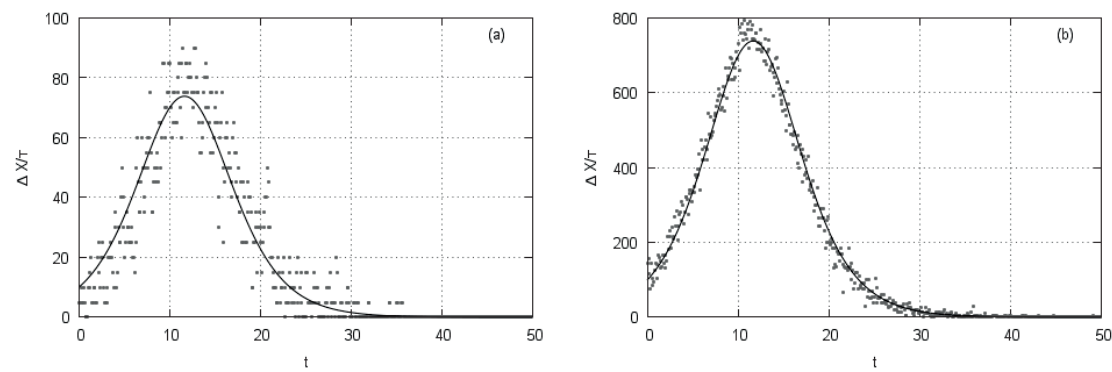

Figure 3. The product adoption, $\Delta t$, per observation interval, $\tau$, curves resulting from the Bass diffusion model (black curves) and the unidirectional agent-based herding model (gray dots). The model parameters were set as follows: $\sigma=0.01, h=0.275$ and $\tau=0.1$ (in both cases), $N=1000$ (a) and $N=10000$ (b).

\section{The extensive and non-extensive agent-based herding model}

In the agent-based models we can assume that agents either interact on the local scale with their immediate neighbors or on the global scale with all of the agents (Purlys et al, 2012). In the former case the number of interaction links per agent remains the same as the system grows, thus the system is extensive, while in the latter case the number of interaction links per agent increases, thus the system is non-extensive. In these two cases rather different behavior would be observed and rather different distributions would be obtained - Gaussian distribution in the extensive case and heavy tailed power-law distributions in the non-extensive one (Tsallis, 2009). 2009)

Stationary probability density function (abbr. PDF) of the SDE is given by (Gardiner,

$$
p(x)=\frac{C}{g^{2}(x)} \exp \left(-2 \int^{x} \frac{f(s)}{g^{2}(s)} \mathrm{d} s\right),
$$


where $C$ is a normalization constant, $f(x)$ is a drift and $g(x)$ is diffusion functions of the SDE. From the above function and the SDE for the non-extensive agent-based herding model the stationary PDF is obtained,

$$
p(x)=\frac{\Gamma\left(\varepsilon_{2}+\varepsilon_{1}\right)}{\Gamma\left(\varepsilon_{2}\right) \Gamma\left(\varepsilon_{1}\right)}(1-x)^{\varepsilon_{2}-1} x^{\varepsilon_{1}-1},
$$

where $\varepsilon_{i}=\sigma_{i} / h$. As you have seen before, the Bass diffusion model is similar - in the extensive case with an infinite population the macroscopic model would be given by ordinary differential equation. In the long run this kind of model would converge to a fixed point. Thus, stationary PDF of such model can be expressed via Dirac's delta function,

$$
p(x)=\delta\left(x-x_{0}\right)
$$

where $x_{0}=\sigma_{1} /\left(\sigma_{1}+\sigma_{2}\right)$ is a fixed point of convergence (in the Bass diffusion model case $x_{0}=1$ ). However, in the agent-based modeling there can be no infinite system size. In the limit of large but finite system the extensive agent-based herding model is well approximated by the

$$
\mathrm{d} x=\left[\sigma_{1}(1-x)-\sigma_{2} x\right] \mathrm{d} t+\sqrt{\frac{2 h x(1-x)+\sigma_{1}(1-x)+\sigma_{2} x}{N}} \mathrm{~d} W .
$$

The probability density function of this stochastic process is similar to Gaussian distribution,

$$
p(x) \approx C^{\prime} \exp \left(-2 \int A\left(s-x_{0}\right) \mathrm{d} s\right)=\sqrt{\frac{N A}{\pi}} \exp \left[-N A\left(x-x_{0}\right)^{2}\right],
$$

where $C^{\prime}$ is a normalization constant and $A$ is a first-order coefficient of the Taylor expansion of $f(x) / g^{2}(x)$ near $x_{0}$. As you can see, the width of this stationary PDF is inversely proportional to $\sqrt{N}$, consequently, in the limit of large populations the probability density function converges to the Dirac's delta function.

\section{Leadership in the agent-based herding model}

Social herding behavior leads to a collective decision making and raises a question of the importance of leadership in the social systems. In the modern literature this problem is considered both from the experimental (Dyer et al, 2009) and theoretical (Schweitzer et al, 2012) points of view. The mechanics behind the collective decision making in the agent-based herding model was discussed in the previous sections and should be clear. Yet the formulation of these mechanics implies that one can control the output of the model by including the agents with a preset opinion, the so-called leaders. 
Let us now include $M$ leaders into the agent-based herding model, so that the system is now composed of $N+M$ agents:

$$
P(X \rightarrow X-1)=X\left\lceil\sigma_{2}+h(N-X)\right] \Delta t, \quad P(X \rightarrow X+1)=(N-X)\left(\sigma_{1}+h(M+X)\right) \Delta t .
$$

The corresponding macroscopic model, for $x=X / N$, is given by

$$
\mathrm{d} x=\left[\left(\sigma_{1}+M h\right)(1-x)-\sigma_{2} x\right] \mathrm{d} t+\sqrt{2 h x(1-x)} \mathrm{d} W .
$$

As you can see from the SDE and Figure 4, the leaders effectively increase the attractiveness of the selected state. This intuition is further supported by the mathematical forms of the stationary PDF and mean,

$$
p(x)=\frac{\Gamma\left(\varepsilon_{2}+\varepsilon_{1}+M\right)}{\Gamma\left(\varepsilon_{2}\right) \Gamma\left(\varepsilon_{1}+M\right)}(1-x)^{\varepsilon_{2}-1} x^{\varepsilon_{1}+M-1}, \quad \bar{x}=\frac{\varepsilon_{1}+M}{\varepsilon_{1}+\varepsilon_{2}+M} .
$$

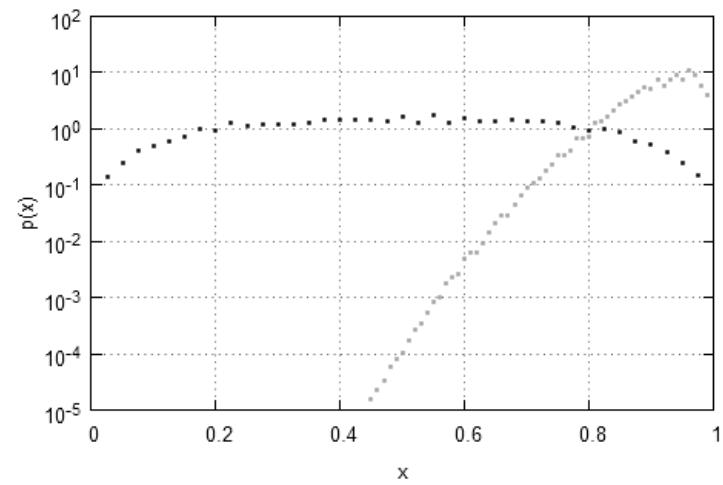

Figure 4. The leaders effect on the stationary PDF of the agent-based herding model. No leader case (black dots) and 20 leader case (gray dots) are shown. Other model parameters were set as follows: $\sigma_{1}=\sigma_{2}=2, h=1$ and $N=1000$.

Apparently, infinitely large social systems can be significantly influenced by a relatively small number of leaders. This is in agreement with the experiments by Dyer et al (2009), who have noticed that 20 informed people can lead large uninformed crowds. Arguably similar ideas might be already used as the marketing strategies (Kononovicius, 2012; Prasad and Mahajan, 2003).

\section{The agent-based herding model versus Lotka-Volterra model}

Lotka-Volterra model was introduced as a macroscopic predator-prey model (Hoppensteadt, 2006), yet now it is a prominent model in a wide range of fields. Its 
applications include macroeconomics (Goodwin, 1967; Tramontana, 2010), complexity science (Olivera et al, 2011), opinion dynamics (Ausloos, 2009; Vitanov and Ausloos, 2012), financial markets (Solomon and Richmond, 2001) and others. Its general form is given by (Hoppensteadt, 2006):

$$
\partial_{t} X_{i}=a_{i} X_{i}-X_{i} \sum_{j} c_{j} X_{j}
$$

where $a_{i}$ is a birth rate, while $c_{i j}$ describes the interaction between the two species.

The most important difference between agent-based herding model and LotkaVolterra model is that the former uses fixed number of agents, while the latter allows creation and destruction of the agents. The Lotka-Volterra model can be seen as interacting with the thermostat, with which the modeled system exchanges agents. Introducing this feature into the agent-based herding model is a pretty technical task, so we skip the details and present only the macroscopic model:

$$
\mathrm{d} x=\left[\sigma_{1}(n-x)-\sigma_{2} x+T_{1}(x, n)\right] \mathrm{d} t+\sqrt{2 h x(n-x)} \mathrm{d} W, \quad \partial_{t} n=T_{1}(x, n)+T_{2}(x, n)
$$

where $T_{i}(x, n)$ is a generalized interaction function between the thermostat and the certain state, given by index $i$, in the system via creation or destruction of the agents in that state. The effect of this modification is only limited by the form of $T_{i}(x, n)$, yet the most straightforward use would be to introduce diffusion limiting, i.e. disallowing overly large or small $x$ values, into the model. This might be of a certain use in the financial market modeling (Gontis et al, 2008; Gontis et al, 2010).

Another important difference is that the agent-based herding model assumes that the herding is symmetrical, while it is asymmetrical in the Lotka-Volterra model. The difference arises from the fact that the agent-based herding model assumes that the nature of the agents is similar, while the interactions are considered to be of predator-prey type by the Lotka-Volterra model. Yet the asymmetry can be easily introduced into the agentbased herding model,

$$
P(X \rightarrow X-1)=X\left[\sigma_{2}+h(N-X)\right] \Delta t, \quad P(X \rightarrow X+1)=(N-X)\left[\sigma_{1}+\left(\frac{c}{N}+h\right) X\right] \Delta t,
$$

where $c$ describes the herding asymmetry. The corresponding macroscopic model is given by:

$$
\mathrm{d} x=\left[\sigma_{1}(1-x)-\sigma_{2} x+c x(1-x)\right] \mathrm{d} t+\sqrt{2 h x(1-x)} \mathrm{d} W
$$

In this case, the original stationary PDF is shifted by the exponential term in the direction of the asymmetry,

$$
p(x) \sim(1-x)^{2^{-1}} x^{\varepsilon_{1}-1} \exp (c x)
$$

See Figure 5 for the results obtained from the agent-based model. 


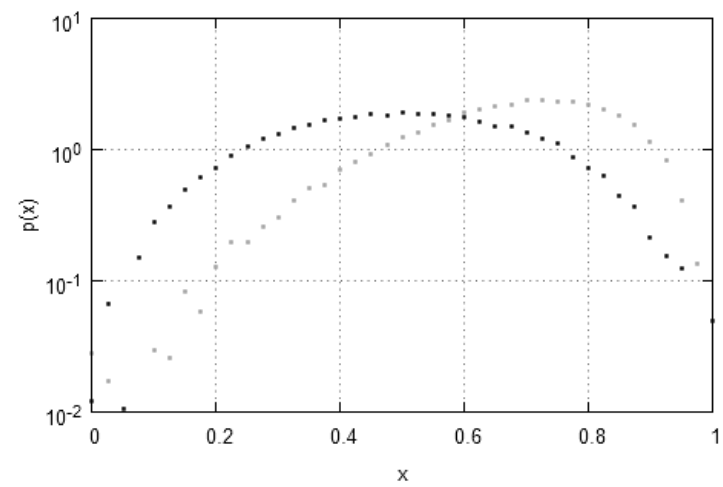

Figure 5. The effect of asymmetric herding on the stationary PDF of the agent-based herding model. Black dots correspond to the symmetric herding case, $c=0$, while the gray dots correspond to a certain asymmetric case, $c=5$. Other model parameters were set as follows: $\sigma_{1}=\sigma_{2}=2, h=1$ and $N=1000$.

\section{General class of stochastic differential equations and the agent-based herding model for the financial markets}

Previously our research group proposed sophisticated double stochastic models for the trading activity and the absolute return in the financial markets (Gontis et al, 2008; Gontis et al, 2010). These two models are able to reproduce the sophisticated statistical features of the high-frequency financial market data rather well. Despite being different in the details, these two models share the same base. They are both driven by the empirically derived SDE, general form of which is given by

$$
\mathrm{d} y=\left(\eta-\frac{\lambda}{2}\right) y^{2 \eta-1} \mathrm{~d} t+y^{\eta} \mathrm{d} W
$$

Time series obtained by solving this SDE are known to have power law statistical properties - power spectral density (abbr. PSD) and stationary PDF (Ruseckas and Kaulakys, 2011),

$$
S(f) \sim 1 / f^{\beta}, \quad \beta=1+\frac{\lambda-3}{2 \eta-2}, \quad p(y) \sim y^{-\lambda} .
$$

We will derive this SDE from an agent-based model and, consequently, provide a general agent-based background for the financial market fluctuations.

To start, let us use a very common assumption that agents can use either fundamentalist or noise trading, chartist, strategies (Cristelli et al, 2012). Fundamentalist agents are assumed to possess a certain knowledge about the stock, which is mathematically formalized as a fundamental price, $P_{f}$. As these agents assume that the price of the 
stock will converge towards $P_{f}$ (the market price will reflect knowledge), they sell, if $P(t)>P_{f}$, or buy, if $P(t)<P_{f}$. Consequently, their excess demand is given by

$$
D_{f}(t)=N_{f}(t) \mathrm{h} \frac{P_{f}}{P(t)}, \quad N_{f}(t)=N-X(t) .
$$

Note that we have assumed that the fundamental price is constant, because we are interested in the endogenous dynamics.

The noise traders are assumed to use a wide variety of strategies relying on the past movements of the stock price. As the variety of strategies may be very large, the input of these agents can be related to an average mood, $\xi(t)$ :

$$
D_{n}(t)=r_{0} N_{n}(t) \xi(t), \quad N_{c}(t)=X(t)
$$

where $r_{0}$ is a relative impact of the noise trader agent.

Now, let us use the Walrasian scenario to obtain the stock price from the excess demand,

$$
\frac{1}{\beta P} \partial_{t} P=D_{f}+D_{n}, \quad \frac{1}{\beta N} \partial_{t} p \approx 0=(1-x) p+r_{0} x \xi, \quad p=\ln \left(\frac{P}{P_{f}}\right), \quad p=-\frac{r_{0} x \xi}{1-x},
$$

where we approximate the Walrasian scenario in the limit of an infinite population. Consequently, the return is given by

$$
r(t)=p(t)-p(t-\Delta t)=-\frac{r_{0} x(t) \xi(t)}{1-x(t)}+\frac{r_{0} x(t+\Delta t) \xi(t+\Delta t)}{1-x(t+\Delta t)} \approx r_{0} y(t) \eta(t),
$$

where we have assumed that $y(t)=x(t) /[1-x(t)]$ is a slowly varying absolute return process and $\eta(t)=\xi(t-\Delta t)-\xi(t)$ represents fast mood fluctuations. Due to the large variety of the noise trading strategies, $\eta(t)$ can be assumed to be a simple noise (Alfarano et al, 2005). In such case, all of the relevant dynamics are included in the absolute return. Macroscopic model for $y$ is easily obtained from the SDE for $x$ by using Ito variable substitution (Gardiner, 2009),

$$
\mathrm{d} y=\left(\sigma_{1}-y\left[\sigma_{2}-2 h\right]\right)(1+y) \mathrm{d} t+\sqrt{2 h y}(1+y) \mathrm{d} W .
$$

As the derivation of this SDE does not depend on the actual form of $\sigma_{i}$ and $h$, they might be assumed to be functions of either $x$ or $y$. 
Original agent-based herding model assumes that agents interact at a constant rate, while in the actual complex socio-economic systems interaction rates might be variable. In the financial markets this phenomenon is observed as fluctuating trading activity. So, let us assume that the herding behavior and the individual behavior of the noise traders are dependent on the global system state via a custom $\tau(y)$ function (Kononovicius et al, 2012),

$$
\mathrm{d} y=\left(\varepsilon_{1}-y \frac{\varepsilon_{2}-2}{\tau(y)}\right)(1+y) \mathrm{d} t_{s}+\sqrt{\frac{2 y}{\tau(y)}}(1+y) \mathrm{d} W_{s}, \quad t_{s}=h t .
$$

In the limit of large $y$ and by assuming that $\tau(y)=y^{-\alpha}$, the above equation is reduced to SDE,

$$
\mathrm{d} y=\left(2-\varepsilon_{2}\right) y^{2+\alpha} \mathrm{d} t_{s}+\sqrt{2 y^{3+\alpha}} \mathrm{d} W_{s},
$$

identical to the previously discussed general class of the SDEs. The relationship between the model parameters is given by $2 \eta=3+\alpha$ and $\lambda=\varepsilon_{2}+\alpha+1$. Note that we can use these relations and theoretical predictions by Ruseckas and Kaulakys (2011) to reproduce PDF and PSD with very different power-laws $\lambda$ and $\beta$ (see Figure 6).

For interactive program of this model, see Kononovicius and Gontis, 2012.
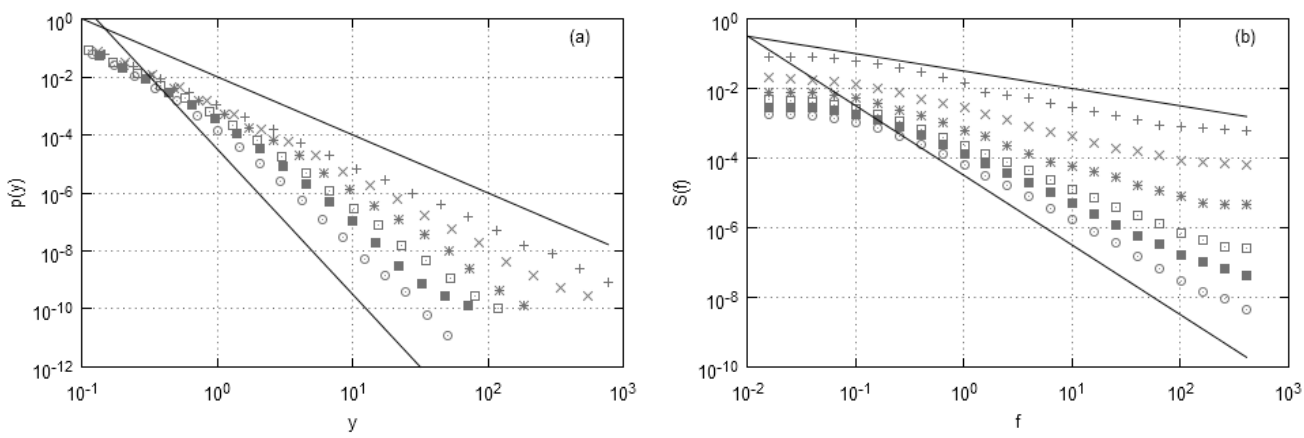

Figure 6. Wide spectra of obtainable probability (a) and spectral (b) density functions of absolute return, $y$. Black lines correspond to the limiting, minimum and maximum, exponents: (a) $\lambda_{\min }=2$ and $\lambda_{\max }=5$, (b) $\beta_{\min }=0.5$ and $\beta_{\max }=2$. Model parameters were set as follows: $N=1000, \alpha=1, \sigma_{1}=0.1, h=1, \sigma_{2}=0.1$ (plus), 0.5 (cross), 1 (star), 1.5 (open square), 2 (filled square) and 3 (open circle). 


\section{Conclusions}

We have discussed our approaches to a simple agent-based herding model proposed by Kirman (1993). Despite its simplicity, this agent-based herding model captures or can be easily modified to capture essential features of the social behavior in many different complex socio-economic systems.

We have reviewed extensive and non-extensive approaches to the agent-based herding model. We have analytically shown that in the extensive, i.e. local interaction case with a finite population Gaussian distribution is obtained. In the non-extensive, i.e. global interaction case, we have shown that power-law distribution emerges.

We have modified the agent-based herding model to show that even small amount of leaders, agents with preset opinion, can influence the behavior of an infinitely large social system. Namely, we have injected agents with a preset opinion and observed that the whole population of the non-leaders, agents with no preset opinion, shifts its mean opinion towards the opinion held by the injected leaders. Apparently, the shift in the mean opinion depends only on the number of the leaders and not on the size of the social system.

We have also shown that the well-known prey-predator model, or Lotka-Volterra model, can be related to the agent-based herding model and used to introduce the interaction with thermostat. This result can be further used to introduce the diffusion limiting in the similar manner as it was done in the previous works related to the financial market modeling (Gontis et al, 2008; Gontis et al, 2010).

In the future we hope to apply this agent-based herding model to more socioeconomic systems. Also, the new approaches discussed in this work will be considered for the extended treatment.

\section{References}

Alfarano, S.; Lux, T.; Wagner, F. Estimation of agent-based models: the case of an asymmetric herding model. Computational Economics. 2005, 26: 19-49.

Alfi, V.; Cristelli, M.; Pietronero, L.; Zaccaria, A. Minimal Agent Based Model for Financial Markets I: Origin and Self-Organization of Stylized Facts. European Physics Journal B. 2009a, 67: 385-397.

Alfi, V.; Cristelli, M.; Pietronero, L.; Zaccaria, A. Minimal Agent Based Model for Financial Markets II: Statistical Properties of the Linear and Multiplicative Dynamics. European Physics Journal B. 2009b, 67: 399-417.
Arthur, W. B. Inductive Reasoning and Bounded Rationality. American Economic Review. 1994, 84: 406-411.

Ausloos, M. On religion and language evolutions seen through mathematical and agent based models. Proceedings of the First Interdisciplinary Chess Interactions Conference. 2009: 157-182.

Axelrod, R. Advancing the art of simulation in the social sciences. Complexity. 1997, 3: 16-32.

Bouchaud, J. P. Economics needs a scientific revolution. Nature. 2008, 455: 1181.

Bouchaud, J. P. The (unfortunate) complexity of the economy. Physics World. 2009: 28-32. 
Bornholdt, S. Expectation bubbles in a spin model of markets: Intermittency from frustration across scales. International Journal of Modern Physics C. 2001, 12: 667-674.

Challet, D.; Marsili, M.; Zecchina, R. Statistical Mechanics of Systems with Heterogeneous Agents: Minority Games. Physical Review Letters. 2000, 84: 1824-1827.

Chakraborti, A.; Toke, I. M.; Patriarca, M.; Abergel, F. Econophysics review: II. Agentbased models. Quantitative Finance. 2011, 7: 1013-1041.

Colander, D.; Goldberg, M.; Haas, A.; Juselius, K.; Kirman, A.; Lux, T.; Sloth, B. The financial crisis and the systemic failure of the economics profession. Critical Review. 2009, 21: 249-267.

Cristelli, M.; Pietronero, L.; Zaccaria, A. Critical overview of agent-based models for economics. Proceedings of the School of Physics "E. Fermi", course CLXXVI. Bologna: SIF, 2012.

Dyer, J. R. G.; Johansson, A.; Helbing, D.; Couzin, I. D.; Krause, J. Leadership, consensus decision making and collective behaviour in humans. Philosophical Transactions of the Royal Society B. 2009, 364: 781-789.

Farmer, J. D.; Foley, D. The economy needs agent-based modeling. Nature. 2009, 460: 685-686.

Farmer, J. D.; Gallegati, M.; Hommes, C.; Kirman, A.; Ormerod, P.; Cincotti, S.; Sanchez, A.; Helbing, D. A complex systems approach to constructing better models for managing financial markets and the economy. European Physics Journal Special Topics. 2012, 214: 295-324.

Feng, L.; Li, B.; Podobnik, B.; Preis, T.; Stanley, H. E. Linking agent-based models and stochastic models of financial markets. Proceedings of the National Academy of Sciences of the United States of America. 2012, 22: 8388-8393.

Gardiner, C. W. Handbook of stochastic methods. Berlin: Springer, 2009.
Goodwin, R. M. A growth cycle. Socialism, capitalism and economic growth. Cambridge: Cambridge University Press, 1967.

Gontis, V.; Kaulakys, B.; Ruseckas, J. Trading activity as driven Poisson process: comparison with empirical data. Physica A. 2008, 387: 3891-3896.

Gontis, V.; Ruseckas, J.; Kononovicius, A. A long-range memory stochastic model of the return in financial markets. Physica A. 2010, 389: 100-106.

Helbing, D. Pluralistic modeling of complex systems. Science and Culture. 2010, 76: 315.

Hoppensteadt, F. 2006. Predator-prey model. Scholarpedia. 2006, 1: 1563.

Jeanblanc, M.; Yor, M.; Chesney M. Mathematical Methods for Financial Markets. Berlin: Springer, 2009.

van Kampen, N. G. Stochastic process in physics and chemistry. Amsterdam: North Holland, 2007.

Kirman, A. P. Ants, rationality and recruitment. Quarterly Journal of Economics. 1993, 108: 137-156.

Kitov, I. O. Does economics need a scientific revolution? Munich Personal RePEc Archive. 2009, 14476.

Kononovicius, A. Kirman's ant colony model. Physics of Risk. 11 April, 2010 [interactive]. [accessed on 04-03-2013]. <http:// mokslasplius.lt/rizikos-fizika/en/kirmanants>.

Kononovicius, A.; Gontis, V. Stochastic ant colony model. Physics of Risk. 28 October, 2010 [interactive]. [accessed on 04-032013]. <http://mokslasplius.lt/rizikos-fizika/ en/stochastic-ant-colony-model>.

Kononovicius, A.; Gontis, V.; Daniunas, V. Unidirectional Kirman's model. Physics of Risk 10 June, 2011 [interactive]. [accessed on 04-03-2013]. <http://mokslasplius.lt/rizikosfizika/en/unidirectional-kirman-model $>$.

Kononovicius, A.; Gontis, V. Agent based herding model of financial markets. Physics of Risk 8 July, 2011 [interactive]. [accessed on 04-03-2013]. <http://mokslasplius.lt/ rizikos-fizika/en/agent-based-herdingmodel-financial-markets $>$. 
Kononovicius, A. What can the Bass diffusion model tell us about piracy? Physics of Risk 19 March, 2012 [interactive]. [accessed on 04-03-2013]. <http://mokslasplius.lt/rizikosfizika/en/what-can-the-bass-diffusionmodel-tell-us-about-piracy>.

Kononovicius, A.; Gontis, V.; Daniunas, V. Agent-based versus macroscopic modeling of competition and business processes in economics and finance. International Journal On Advances in Intelligent Systems. 2012, 5: 111-126.

Krause, S. M.; Bottcher, P.; Bornholdt, S. Meanfield-like behavior of the generalized votermodel-class kinetic Ising model. Physical Review E. 2012, 85: 031126.

Lux, T.; Marchesi, M. Scaling and criticality in a stochastic multi-agent model of a financial market. Nature. 1999, 397: 498-500.

Olivera, N. L.; Proto, A. N.; Ausloos, M. Information society: Modeling a complex system with scarce data. Proceedings of The V Meeting on Dynamics of Social and Economic Systems. 2011, 6: 443-460.

Pasteels, J. M.; Deneubourg, J. L.; Goss, S. Selforganization mechanisms in ant societies. From Individual to Collective Behaviour in Social Insects. Basel: Birkhauser, 1987.

Pietronero, L. Complexity ideas from condensed matter and statistical physics. Europhysics News. 2008,39: 26-29.

Purlys, P.; Kononovicius, A.; Gontis, V. Various ways of introducing herding behavior into the agent based models of complex systems. Open Readings 2012: 150. Vilnius: Vilnius University Press, 2012.

Prasad, A.; Mahajan, V. How many pirates should a software firm tolerate? An analysis of piracy protection on the diffusion of software. International Journal of Research in Marketing. 2003, 20: 337-353.

Ruseckas, J.; Kaulakys, B. Tsallis distributions and $1 / \mathrm{f}$ noise from nonlinear stochastic differential equations. Physical Review E. 2011, 84: 051125.

Samanidou, E.; Zschischang, E.; Stauffer, D.; Lux, T. Agent-based models of financial markets. Reports on Progress in Physics. 2007, 70: 409.

Schweitzer, F.; Mavrodiev, P.; Tessone, C. J. How can social herding enhance cooperation? CoRR. 2012, abs/1211.1188.

Sethna, J. P. Statistical Mechanics: Entropy, Order Parameters and Complexity. Oxford: Clarendon Press, 2009.

Solomon, S.; Richmond, P. Stability of ParetoZipf law in non-stationary economies. Lecture Notes in Economics and Mathematical Systems. 2001, 503: 141-159.

Tramontana, F. Economics as a compartmental system: a simple macroeconomic example. International Review of Economics. 2010, 57: 347-360.

Tsallis, C. Introduction to nonextensive statistical mechanics: Approaching a complex world. New York: Springer, 2009.

Vitanov, N. K.; Ausloos, M. Discrete model of ideological struggle accounting for migration. Advances in Complex Systems. 2012, 15: 1250049.

Waldrop, M. Complexity: The emerging order at the edge of order and chaos. New York: Simon and Schuster, 1992. 


\title{
SUDĖTINGŲ SOCIALINIŲ IR EKONOMINIŲ SISTEMŲ MODELIAVIMAS AGENTŲ MODELIAVIMO IR MAKROSKOPINIAIS METODAIS
}

\author{
Aleksejus Kononovičius \\ Vilniaus universiteto Teorinės fizikos ir astronomijos institutas, Lietuva, \\ alekejus.kononovicius@gmail.com

\section{Valentas Daniūnas} \\ Mokslininkų sajungos institutas, Lietuva, mokslasplius@itpa.lt
}

Santrauka. Šiame darbe nagrinejame sąsajas tarp kolektyvinés elgsenos ir individu tarpusavio sqqueikos sudetingose socialinèse ir ekonominese sistemose. Šiuo metu yra publikuota nemažai darbu, kuriuose siülomi ivvairüs individu tarpusavio squeikos socialinèse ir ekonominèse sistemose modeliai. Mokslinejje literatūroje taip pat pastebimas nemenkas susidoméjimas makroskopiniu, arba kolektyvines elgsenos, modeliavimu. Nepaisant aktyvaus domejjimosi idealaus modelio lig šiol vis dar nèra pasiülyta. Ši problema iš esmés yra susijusi su tuo, kad idealus modelis turètu susieti sias dvi squokas. Kolektyvine elgsena dažnai modelinojama stochastines ir matematines analizés ịrankiais, sie modeliai yra vadinami makroskopiniais modeliais, o individu tarpusavio saqvikos modeliuojamos naudojant agentu formalizmą. Siekiant pasiülyti idealu modeli reiktu suprasti saryšius tarp šiu dvieju matematiniu formalizmu. Tai yra sunki užduotis, jei bandome ieškoti ryšiu pradedami nuo makroskopiniu modeliu ir siekdami iš ju suprasti individu tarpusavio saveikas. Nemažiau sudetingas atrodytu ir bandymas pradeti iš kitos puses, tačiau jei pasirinksime elementaru individu tarpusavio sąveiku modeli, sunkumu kilti neturètu. Taigi ieškodami saryšiz tarp kolektyvinès elgsenos ir individu tarpusavio saveiku visu pirma turime pradeti nuo elementariu agentu modeliu ir tik veliau pildyti juos sudètingesne elgsena. Šios paieškos domina įvairiausiu mokslu sričiu mokslininkus. Vis dellto pakankamai demesio šiai temai buvo skirta tik pastaraisiais metais, tad darbai, bandantys tiesiogiai susieti agentu ir makroskopinius modelius, vis dar yra gana reti. Šie darbai, nors siekia tokiu pačiu tikslu, taip pat yra gana skirtingi - dalis mokslininku grupiu kuria agentu modelius besiremdami apklausu duomenimis, kad suprastu individualia žmoniu elgsena, dalis mokslininku bando taikyti ivvairius fizikinius modelius socialiniams reiskiniams modeliuoti, dalis remiasi elgsenos ekonomikos pasiekimais ar naudos funkciju optimizavimo idejja. Müsu grupés tyrimai remiasi elementariu dvieju büsenu agentu bandos jausmo modeliu, kuri 1993 metais pasiüle A. Kirman. Šis modelis yra gana universalus, nes atsižvelgia tik ic esminius ir universaliausius socialinio elgesio aspektus - polinki i individualizma ir nora priklausyti bendruomenei. Šiame darbe mes apžvelgeme keleta galimu šio modelio taikymu. Visu pirma mes pademonstravome, kad sis modelis yra mikroskopinis Bass'o sklaidos modelio, kuris yra plačiai naudojamas marketingo teorijoje, analogas. Kitas gerai žinomas ir plačiai ivairiausiu socialiniu ir ekonominiu sistemu modeliavimui naudojamas makroskopinis Lotka-Volterra modelis taip pat gali büti susietas su agentu bandos jausmo 
modeliu. Iš Kirman'o agentu modelio išvedème lygtis, kurios gali büti tinkamos finansu rinku modeliavimui. Šiame darbe palieteme ir labai svarbia lyderystés socialinese bendruomenese tema ir parodeme, kad agentu noras priklausyti bendruomenei sudaro prielaidas netiesiogiai valdyti visos sistemos elgsena.

Reikšminiai žodžiai: socialinès ir ekonomines sistemos, agentu modeliai, stochastiniai modeliai. 